\title{
Spatial forecasting of red palm mite in Brazil under current and future climate change scenarios
}

\author{
Denise Navia(1), Emília Hamada(2), Manoel Guedes Correa Gondim Jr. ${ }^{(3)}$ and Norton Polo Benito(1)
}

\begin{abstract}
(1)Embrapa Recursos Genéticos e Biotecnologia, Parque Estação Biológica, Avenida W5 Norte (Final), Caixa Postal 02372, CEP 70770-917 Brasília, DF, Brazil. E-mail: denise.navia@embrapa.br, norton.benito@embrapa.br (2)Embrapa Meio Ambiente, Rodovia SP-340, Km 127,5, Tanquinho Velho, Caixa Postal 69, CEP 13820-000 Jaguariúna, SP, Brazil. E-mail: emilia.hamada@embrapa.br (3)Universidade Federal Rural de Pernambuco, Rua Dom Manoel de Medeiros, s/nº, Dois Irmãos, CEP 52171-900 Recife, PE, Brazil. E-mail: mguedes@depa.ufrpe.br
\end{abstract}

\begin{abstract}
The objective of this work was to predict the spatial distribution of the red palm mite, Raoiella indica (Acari: Tenuipalpidae), in Brazil under current and future climate change scenarios. A mapping method of species distribution based on the geographic information system (GIS) was used. The maps were constructed taking into account ranges of favorability for temperature and relative humidity. Favorability levels were defined considering the available information on pest biology and population dynamics. To characterize the current climatic conditions, information was referenced to the climate normal from 1961 to 1990. Future scenarios for the models were the A2 and B1 gas emission scenarios from the Intergovernmental Panel on Climate Change, focusing on the periods of 2011-2040, 2041-2070, and 2071-2100. The constructed maps showed that, for the reference period, Brazil presents extensive areas with favorable or very favorable conditions for the establishment of red palm mite populations. An increasing favorability was observed for future scenarios when compared with the reference period, indicating that the pest impact will worsen if it is already widely spread and causing damage in the country. Under current and future climate scenarios, most of the favorable and very favorable areas for red palm mite are in northeastern Brazil.
\end{abstract}

Index terms: Raoiella indica, coconut, invasive pest, pest management, pest risk analysis, species distribution mapping.

\section{Predição espacial do ácaro-vermelho-das-palmeiras no Brasil sob cenários atual e futuros de mudanças climáticas}

Resumo - O objetivo deste trabalho foi predizer a distribuição espacial do ácaro-vermelho-das-palmeiras, Raoiella indica (Acari: Tenuipalpidae), no Brasil, em cenários atual e futuros de mudanças climáticas. Foi utilizado um método de mapeamento de distribuição de espécies baseado no sistema de informação geográfica (SIG). Os mapas foram construídos considerando faixas de favorabilidade de temperatura e umidade relativa. Os níveis de favorabilidade foram definidos a partir da informação disponível sobre a biologia e a dinâmica populacional da praga. Para caracterizar as condições climáticas atuais, informações foram referenciadas para a normal climatológica de 1961 a 1990. Os cenários futuros para os modelos foram os cenários A2 e B1 de emissões de gases, do Painel Intergovernamental sobre Mudanças Climáticas, focalizados nos períodos de 2011-2040, 2041-2070 e 2071-2100. Os mapas construídos mostraram que, para o período de referência, o Brasil apresenta extensas áreas com condições favoráveis ou muito favoráveis para o estabelecimento de populações do ácaro-vermelho-das-palmeiras. Observou-se aumento de favorabilidade para os cenários futuros quando comparados ao período de referência, o que indica que o impacto da praga se agravará, caso esta já esteja amplamente disseminada e causando danos no País. Nos cenários atual e futuros de mudanças climáticas, a maior parte das áreas favoráveis e muito favoráveis para o ácaro-vermelho-das-palmeiras está no Nordeste do Brasil.

Termos para indexação: Raoiella indica, coqueiro, praga invasora, manejo de pragas, análise de risco de pragas, mapa de distribuição de espécies.

\section{Introduction}

Invasive species and climate change separately represent the two major drivers of ecosystem alterations and are great threats to biodiversity and to production systems, since both can seriously affect global food security (Burgiel \& Muir, 2010; Wheeler \& von Braun, 2013). Invasive pests are among the chief impediments

Pesq. agropec. bras., Brasília, v.51, n.5, p.586-598, maio 2016

DOI: $10.1590 / \mathrm{S} 0100-204 \mathrm{X} 2016000500020$ 
to agricultural productivity (Burgiel \& Muir, 2010), whereas the overall effects of climate change on agriculture are expected to be severely negative (Nelson et al., 2009). The complexity of the interaction between these two global drivers has increased, and there is rapidly-growing evidence of how climate change is adding to the devastating effects of invasive species (Burgiel \& Muir, 2010).

Whether a newly-introduced species becomes invasive or not depends on the biological and physical characteristics of the habitat where it was introduced, which are greatly influenced by climate (Ziska et al., 2011). Evaluations by the Intergovernmental Panel on Climate Change (2015) indicate that the rise of $\mathrm{CO}_{2}$ and of associated greenhouse gases could lead to an increase in global surface temperatures, as well as to changes on precipitation frequency and intensity (Houghton et al., 2001). Potential consequences of climate change for invasive species are: the establishment of new invasive species, which can successfully survive in localities where climate conditions were unfavorable and became suitable; altered mechanisms of transport and introduction, in which the movement of invasive species at regional and global scales can be facilitated by extreme weather events, whose severity is increasing with climate changes, such as hurricanes, floods, or currents; the reduction in the effectiveness of control strategies, e.g., a decline in the chemical efficacy of herbicides on invasive plants with rising $\mathrm{CO}_{2}$ levels; and pest distribution extension, that is, the enlargement of the altitudinal or latitudinal distribution range of pests (Hellmann et al., 2008; Burgiel \& Muir, 2010). Global warming impacts are likely to increase opportunities for invasive species due to their typical high tolerance to extreme conditions and adaptability to disturbance (Burgiel \& Muir, 2010). Each species and environment presents its own particularities that need to be analyzed individually.

Although species distribution modelling is widely used as a tool to predict the distribution of invasive species and even though these models were recently used in simulations on the effects of future climate scenarios on pests (Franklin, 2009), few studies that jointly analyze the interaction of these two drivers of ecosystem alterations have been conducted. Analyses on the potential effects of climate changes on pests in Brazil have evolved significantly in recent years, particularly for diseases (Ghini et al., 2008).
However, the potential effects on invasive pests, particularly those with restricted distribution or with an imminent risk of entry, have not yet been evaluated. This information is essential for pest risk evaluation (Burgiel \& Muir, 2010). The addition of the effects of climate change to pest risk analysis can provide direction on how to prioritize risk management efforts to minimize impacts on agricultural systems, on both short- and long-term. Furthermore, knowledge on the areas where an invasive pest can assume its greater importance in the future is essential for agricultural research priority setting.

The red palm mite, Raoiella indica Hirst (Tenuipalpidae), is a remarkable invasive pest in the Americas, where it was first reported in the Caribbean island of Martinique, in 2004 (Flechtmann \& Etienne, 2004). This phytophagous mite was officially regulated as a non-present quarantine pest in Brazil, until it was detected, in 2009, in the state of Roraima (Navia et al., 2011) and then, in 2011, in the state of Amazonas (Rodrigues \& Antony, 2011). The mite is now regulated as a present quarantine pest in the country (Brasil, 2013).

Red palm mite populations can reach high densities and cause significant damage to host plants. The coconut (Cocos nucifera L.) tree is the primary host plant for this mite in the Americas, and significant losses caused by high infestations have been reported in affected areas, of approximately $70 \%$ in Trinidad and Tobago (Peña, 2013). Coconut presents great socioeconomic importance in Brazil, the fourth largest producer worldwide, with an area of approximately 270 thousand hectares (Instituto Brasileiro de Geografia e Estatística, 2011). Besides coconut trees, the red palm mite can infest bananas, heliconias, and several other ornamental or socioeconomically important palm trees; 91 plant species of monocot families were reported as reproductive hosts (Carrillo et al., 2012).

Although the red palm mite has still not reached the main coconut production areas in Brazil, authors have expressed concerns about the major impacts it can cause to the Brazilian agro-industry (Navia et al., 2011; Gondim Jr. et al., 2012). Information about the highest risk areas in the present and in the future are fundamental for the definition of prevention or control strategies to minimize the impact of this pest in the country. Amaro \& Morais (2013) presented a first 
prediction on suitable areas for the red palm mite in South America, based on a maximum entropy model.

The objective of this work was to predict the spatial distribution of the red palm mite (Raoiella indica) in Brazil under current and future climate change scenarios.

\section{Materials and Methods}

The maps of species distribution were constructed based on ranges of favorability for two climatic parameters: temperature and relative humidity, since most of the red palm mite biological studies published to date correlate mite development with these parameters. Four favorability levels were defined for each selected climatic parameter: very favorable, favorable, less favorable, and unfavorable.

Temperature and relative humidity ranges and levels of favorability were defined (Table 1) taking into account information available in the literature on the pest's biological parameters and population dynamics (Moutia, 1958; Nageshachandra \& Channabasavanna, 1984; Gondim Jr. et al., 2012; Taylor et al., 2012). Surely prediction would be more accurate if based on upper and lower developmental thresholds and degree-days needed to complete the life cycle; however, these biological parameters have not yet been determined for this pest.

Average monthly temperatures and relative humidities were obtained from the Data Distribution Centre of the Intergovernmental Panel on Climate Change (2015). To characterize the climatic conditions in Brazil, information was referenced to the climate normal of the period from 1961 to 1990, obtained from the Climate Research Unit (2015).

Table 1. Temperature (T) and relative humidity ranges (RH), as well as favorability levels defined for the red palm mite (Raoiella indica $)^{(1)}$.

\begin{tabular}{|c|c|c|c|}
\hline \multirow{2}{*}{$\begin{array}{l}\text { Temperature } \\
\text { ranges }\left({ }^{\circ} \mathrm{C}\right)\end{array}$} & \multicolumn{3}{|c|}{ Relative humidity ranges (\%) } \\
\hline & $60<\mathrm{RH} \leq 70$ & $70<\mathrm{RH} \leq 80$ & $\mathrm{RH}>80$ \\
\hline $10<\mathrm{T} \leq 18$ & Less favorable Unfavorable & Unfavorable & Unfavorable \\
\hline $18<\mathrm{T} \leq 24$ & Very favorable & Unfavorable & Unfavorable \\
\hline $24<\mathrm{T} \leq 35$ & Very favorable Very favorable & Favorable & Less favorable \\
\hline $35<\mathrm{T} \leq 40$ & Very favorable & Less favorable & Unfavorable \\
\hline
\end{tabular}

Pesq. agropec. bras., Brasília, v.51, n.5, p.586-598, maio 2016 DOI: $10.1590 / \mathrm{S} 0100-204 X 2016000500020$
The availability of global climate models, i.e., general circulation models (GCMs), enabled the application of these spatial increments in the risk evaluations. In a current study, three GCM outputs that present data for these climatic variables were used: Csiro-Mk3.0 (Csiro Marine and Atmospheric Research, Aspendale, Australia), INM-CM3.0 (Institute of Numerical Mathematics, Moscow, Russia), and MIROC3.2 (medres) (Center for Climate System Research, Tokyo, Japan).

The future scenarios used for the models were the $\mathrm{A} 2$ and $\mathrm{B} 1$ gas emission scenarios, focusing on the periods of 2011-2040, 2041-2070, and 2071-2100 (Intergovernmental Panel on Climate Change, 2015). The original data for the South American continent was organized in a computer system for the management of climate data, which was developed using the database management system Firebird 2.0 (Borland Software Corporation, Austin, TX, USA), the Object Pascal language of the Delphi software (Borland Software Corporation, Austin, TX, USA), and the IBExpert tool for data manipulation (IBExpert KG, Hude, Germany), according to the latitudes and longitudes defined by each model. The information pertaining to the Brazilian territory was then selected. The Idrisi 32 GIS tool (Clark Labs, Worcester, MA, USA) was used to prepare the georeferenced maps. Because of the different spatial resolutions of the $\mathrm{GCMs}-1.875^{\circ} \times 1.865^{\circ}$ for CSIRO-Mk3.0, $5.0^{\circ} \times 4.0^{\circ}$ for INM-CM3.0, and $2.81252^{\circ} \times 2.7904^{\circ}$ for MIROC3.2 (medres) -, the data were interpolated by the square inverse distance method, which resulted in a final spatial resolution of $0.5^{\circ} \times 0.5^{\circ}$ in latitude and longitude. The monthly average temperatures and relative humidities for the future scenarios were obtained from the average of the three GCMs, using the geographic information system (GIS) spatial analysis tools (arithmetic operation). Maps of the geographical distribution of favorability for the red palm mite in Brazil were obtained for the climate normal and the A2 and B1 scenarios for future periods, based on the basic weather data entered in the GIS database, to which were applied (logical operation) the combined ranges of temperature and relative humidity described in Table 1 .

\section{Results and Discussion}

The species distribution maps were obtained for the potential distribution of $R$. indica in Brazil under 
the A2 and B1 future scenarios of climate change (Figures 1-3). These scenarios cover a wide range of the main demographic, economic, and technological driving forces of greenhouse gas and sulfur emissions (Houghton et al., 2001). A2 is usually a high-greenhouse gas emission scenario, whereas B1 has low greenhouse gas emission, being considered pessimistic and optimistic, respectively, among the scenarios available from the Intergovernmental Panel on Climate Change (2015). The obtained results showed a tendency for an increase in favorability when compared with the climate normal (1961-1990). Therefore, global warming might result in an increased importance of the red palm mite in the country if it is widely spread and is already causing damage, particularly if it has reached important coconut production areas. A greater increase in favorability was observed under the A2 scenario in comparison with the B1 scenario (Figures 1-4).

For the periods of 2011-2040 and 2041-2070, little difference was observed between favorability maps under the A2 and B1 scenarios. However, differences for the 2071-2100 period were pronounced, i.e., under the A2 scenario there was a smaller area with unfavorable conditions than under the B1 scenario, from January to the following months: March, in the South and Southeast regions of Brazil (Figure 1); August, in the Southeast and Northeast regions (Figure 2); and December, in the Southeast and South regions (Figure 3); there was also a larger area with very favorable conditions when compared to B1, from May to July, in the Northeast and Midwest regions (Figure 2). This result is due to the cumulative effect of greenhouse gas emissions during a longer period. These findings are attributed to the characteristics of the predicted scenario families, i.e., scenario B1 is less pessimistic than scenario A2, based on the assumption of lower greenhouse gas emissions, with smaller population growth and more gradual changes in economic structures (Houghton et al., 2001).

A regional analysis was carried out considering the maps obtained for the reference period and the A2 scenario, for the 2071-2100 period (Figures 1-3), since the most pronounced differences were observed between them.

The North region is the second largest coconut-producing region in Brazil, totaling $10 \%$ of the cultivated area $(27,955$ ha). The state of Pará is the main producer of the region, with 23,388 ha $(8.6 \%$ of the coconut production area); followed by Amazonas, with 3,333 ha (1.2\%); and Tocantins, with 882 ha $(0.3 \%)$ (Instituto Brasileiro de Geografia e Estatística, 2011). Currently, the red palm mite distribution in Brazil is restricted to the North region, mainly to the states of Roraima and Amazonas. In Roraima, this invasive pest disseminated rapidly from the first report in July 2009 (Navia et al., 2011) to February 2011, when it was found in ten municipalities (Gondim Jr. et al., 2012). Apparently the dissemination of the mite in the state of Amazonas has been slower than in Roraima; after its detection in August 2011 (Rodrigues \& Antony, 2011), there is no official report of its occurrence in other municipalities. This was consistent with the favorability maps obtained in the present study for the reference period, which showed favorable conditions for the pest population during most of year and for most of Roraima, whereas less favorable or favorable conditions (just a few areas from July-September) were observed for the state of Amazonas. According to the performed analyses, the increase in favorable areas would be striking in eastern Amazonas and in Pará, from July to October. The state of Pará has the most extensive coconut cultivation in the North region, with cultivation concentrated in the northeast of the state, in the municipalities of Moju and Santa Isabel (Instituto Brasileiro de Geografia e Estatística, 2011). The maps obtained for the reference period showed that, for most of Pará, conditions were less favorable for red mite populations throughout the year, except for a narrow coastal range from September to November, when conditions most likely would not be sufficient for the pest to reach damaging levels. Conversely, for the A2 scenario, favorable conditions would occur in the northeastern part of the region and in Pará, from August to November, which could lead to an increase in the pest population density.

Although in the state of Tocantins coconut cultivation is still restricted, it is increasing quickly. In the A2 climate change scenario, the period with favorable conditions for pest development would extend in this state, i.e., beginning in April instead of May, and, for some months (May, June, and October), the conditions would change from favorable to very favorable. Both factors would allow an earlier pest population increase, which would reach higher densities than for the reference period.

The potential positive effect of climate change on the status and spread of the red palm mite in the 


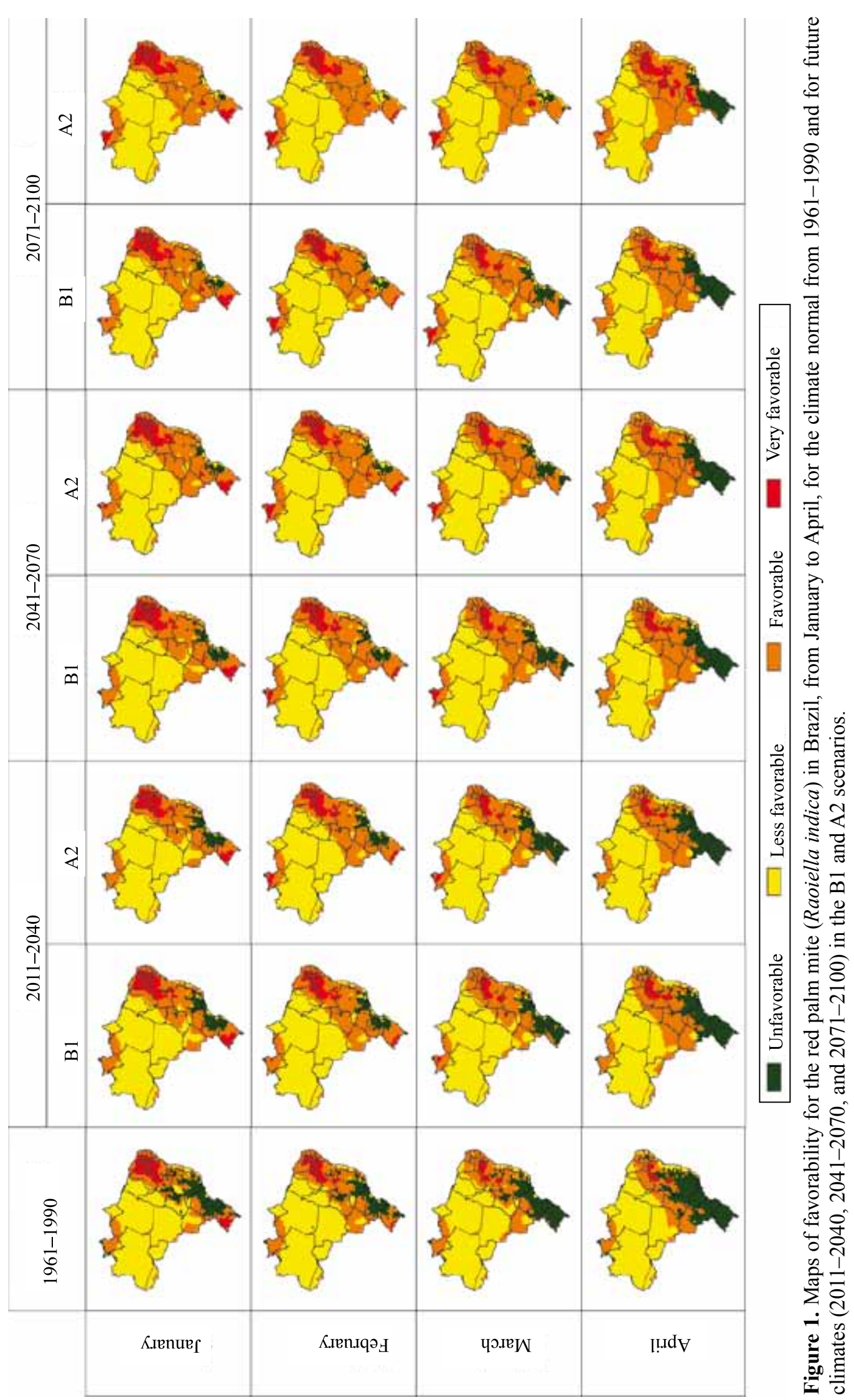




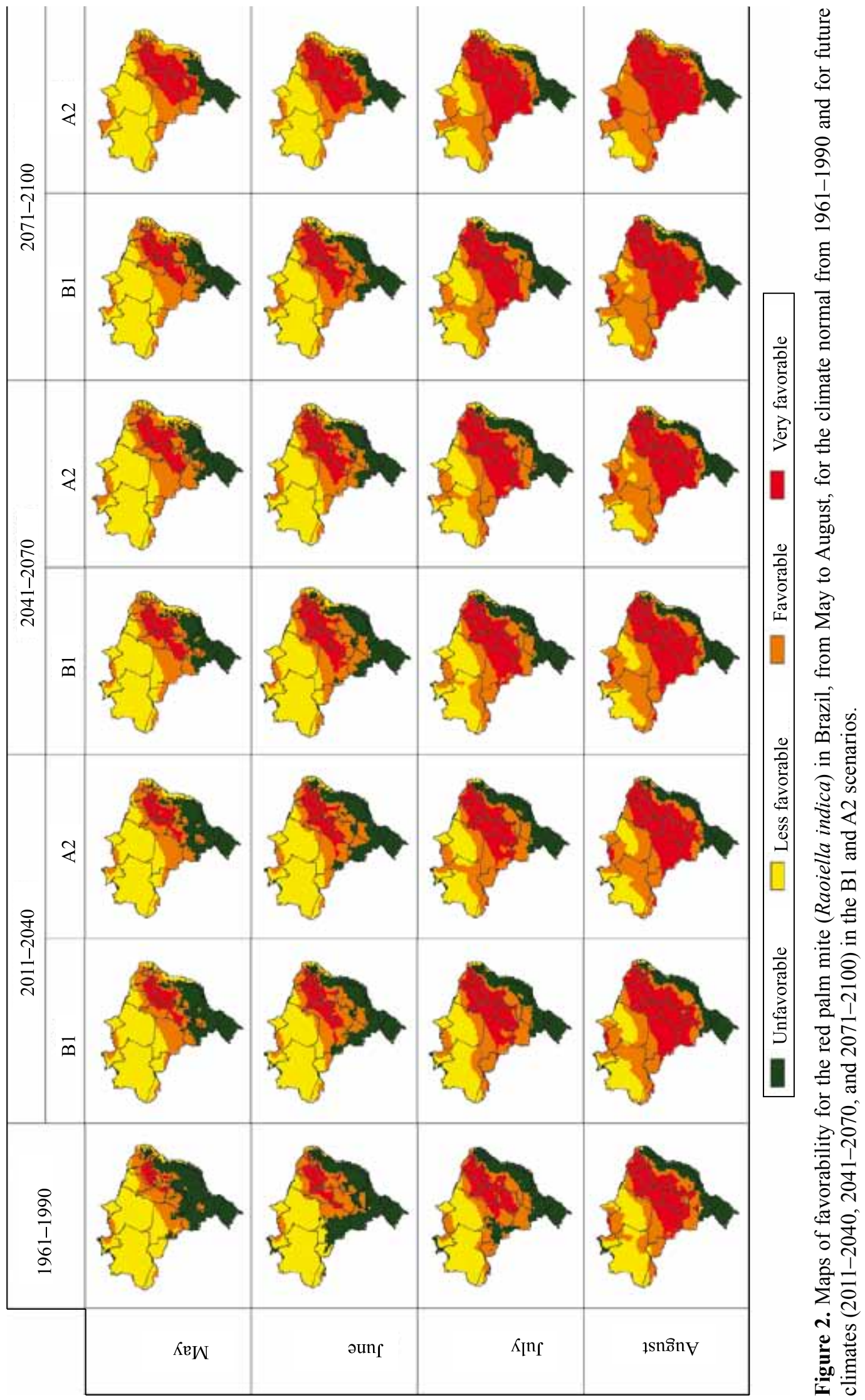




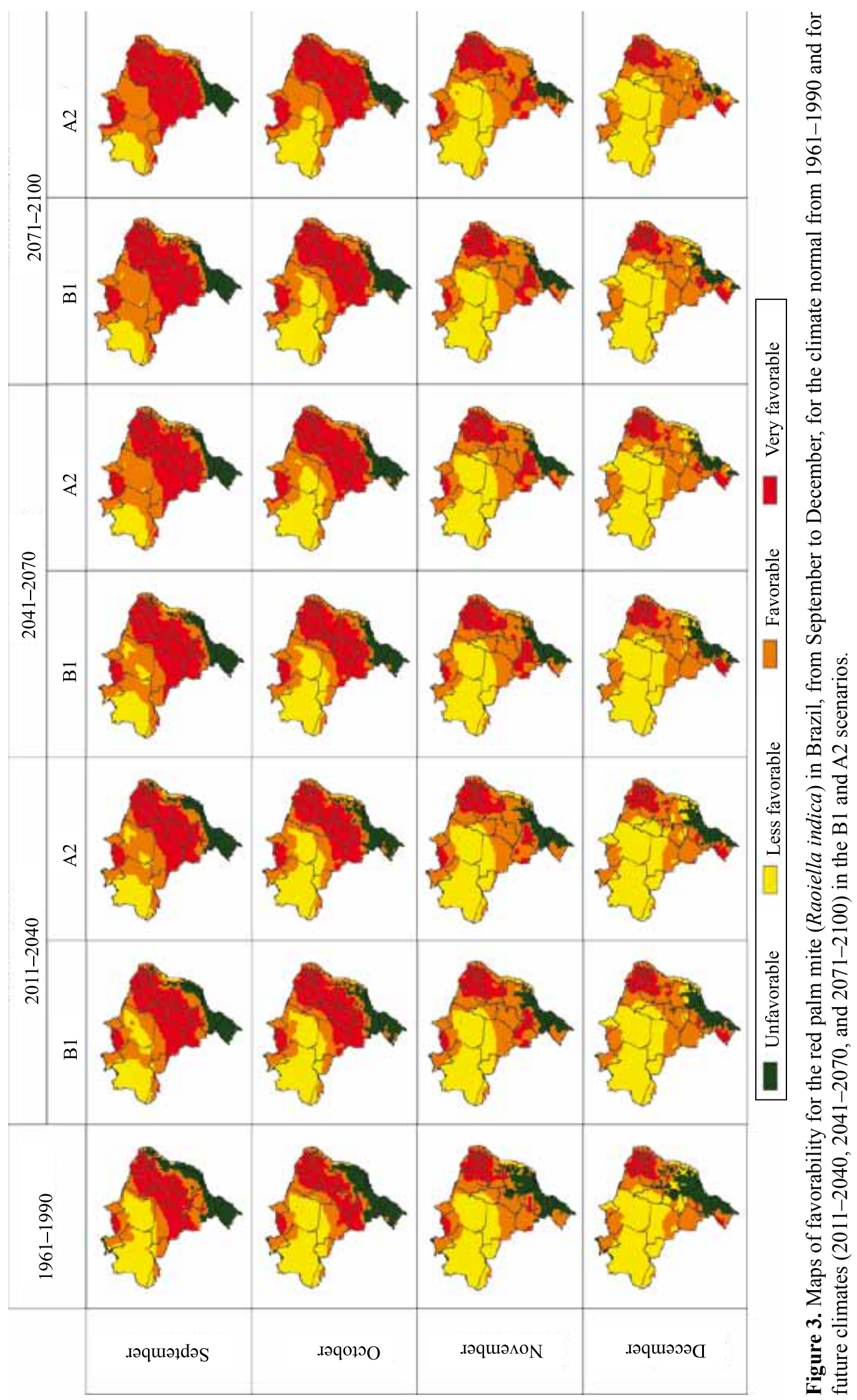




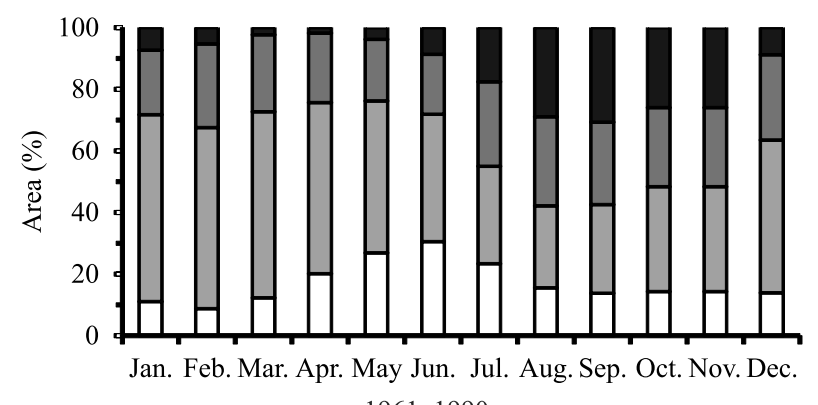

B1 Scenario
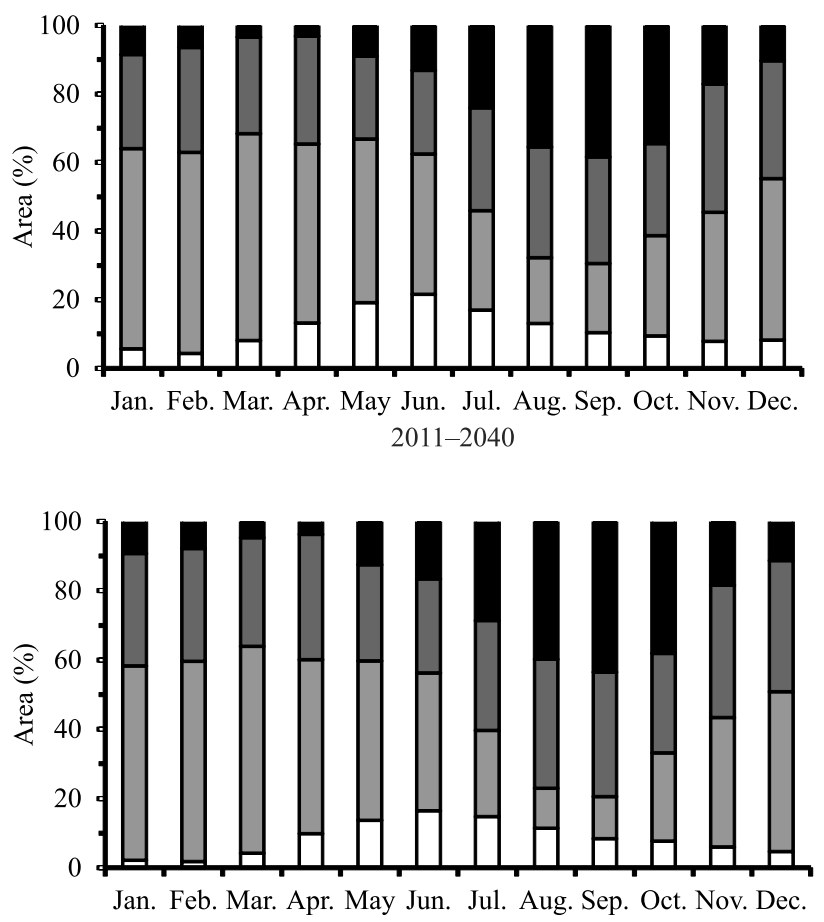
2041-2070

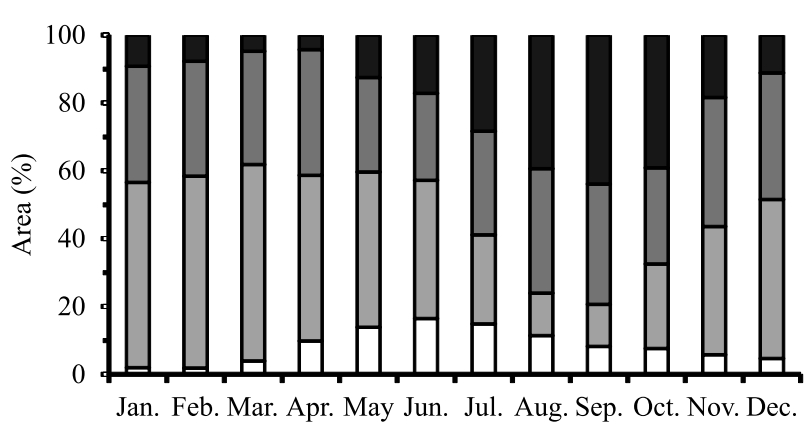
2071-2100
B2 Scenario
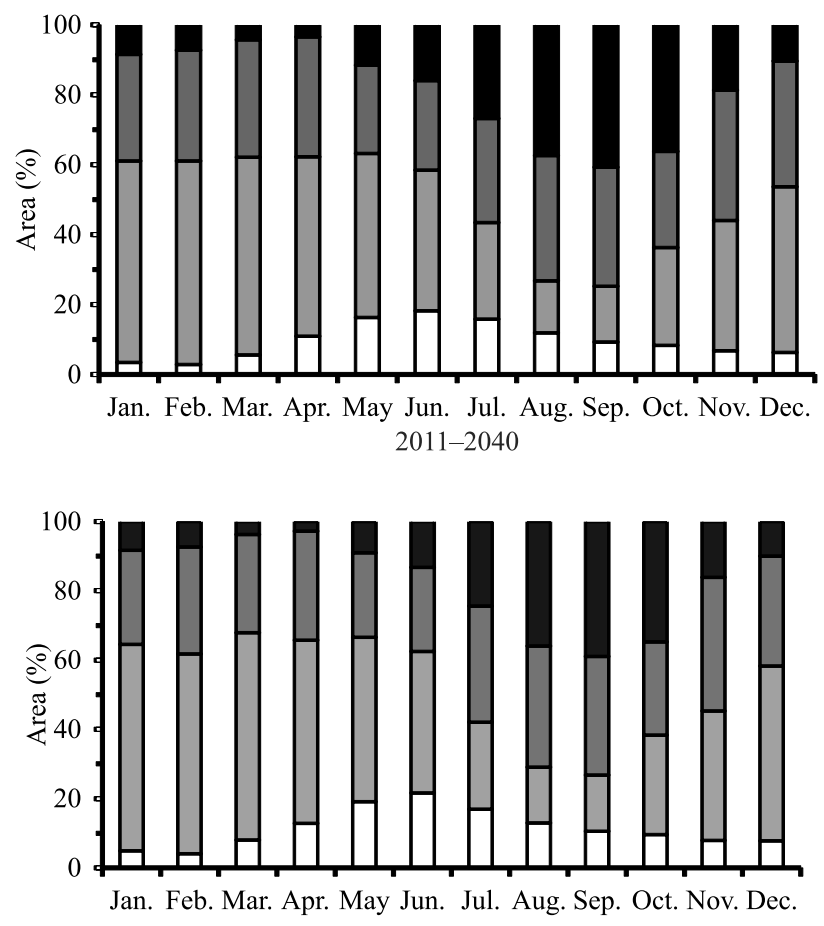
2041-2070

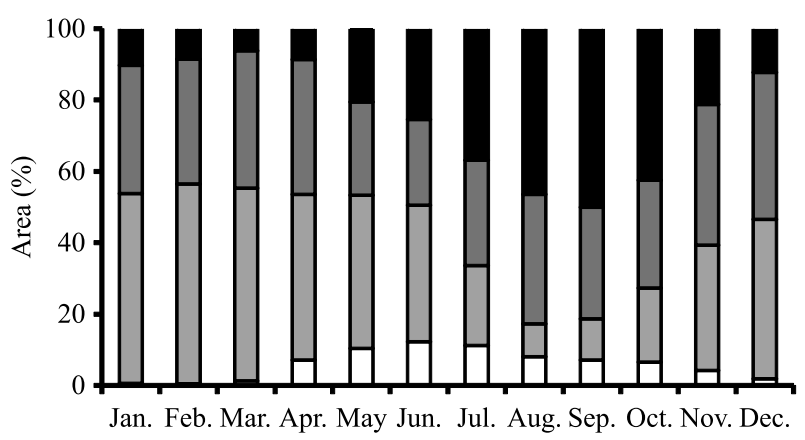

2071-2100

$\square$ Unfavorable $\square$ Less favorable $\quad \square$ Favorable $\quad \square$ Very favorable

Figure 4. Graphs showing variations in the favorability levels for the red palm mite (Raoiella indica) in Brazil, along the year, for the climate normal from 1961-1990 and for future climates (2011-2040, 2041-2070, and 2071-2100) in the B1 and A2 scenarios. 
Amazon region was discussed by Gondim Jr. et al. (2012), who used the population dynamic studies conducted in the state of Roraima to examine the predicted increase in the frequency and severity of drought events in the Amazon region, as a consequence of greenhouse gas emissions (Lewis et al., 2011). The present study supported Gondim Jr. et al. (2012) hypothesis.

The Northeast region comprises approximately $81 \%(219,472$ ha) of the coconut area in Brazil: the state of Bahia is the main producer, with 76,795 ha $(28 \%$ of the coconut production area); followed by Ceará, with 44,800 ha $(16.5 \%)$; Sergipe, with 39,204 ha (14.4\%); Rio Grande do Norte, with 21,725 ha (8\%); Alagoas, with 12,853 ha (4.7\%); Pernambuco, with 10,721 ha (4\%); and Paraíba, with 9,585 ha (3.5\%) (Instituto Brasileiro de Geografia e Estatística, 2011). Favorable and very favorable areas for the development of red palm mite populations were concentrated in this region for almost the entire year, for both the reference period and the A2 climate change scenario (Figures 1-3).

For the reference period, variable levels of favorability for the development of red palm mite populations were observed in different parts of this region. For Ceará, Rio Grande do Norte, inland Pernambuco, and most of Paraíba, Piauí and Sergipe, the maps showed favorable or very favorable conditions throughout the year. Unfavorable areas were observed, particularly during the rainy season, from May to September, in the states of Alagoas, Bahia, Pernambuco, and Paraíba. The primary change forecasted in the A2 scenario was a notable reduction in the unfavorable areas, which remained only in some inland high-altitude areas in the states of Bahia and Pernambuco.

For the A2 scenario, a narrow coastal belt in the states of Alagoas, Bahia, Paraíba, and Pernambuco that was unfavorable for the reference period became less favorable during the rainy season, from May to August. This could cause the stabilization or decline of red palm mite populations during this period. However, populations could recover and reach damaging densities between September and April.

It is also interesting to observe that areas that became favorable for the pest in the northern region, from July to October, were continuous with favorable and very favorable areas in the Northeast. This change in favorability in the North region would favor a pest population increase in the areas where it was already present, increasing propagule pressure, and, consequently, favoring its dissemination in the area as well as to the Northeast region.

In the semiarid areas of the states of Bahia, Pernambuco, Ceará, and Paraíba, coconut is cultivated with a high level of technology and irrigation (Fontes $\&$ Wanderley, 2006). In these areas, for the reference period, conditions were forecasted as favorable or very favorable for the mite populations for the entire or for most of the year. For the A2 scenario, maps showed that favorable areas would become very favorable, which indicated that the climate change scenario would worsen the phytosanitary status of the coconut crop in the northeastern semiarid lands if the red palm mite were established.

The Southeast region is the third Brazilian region in coconut cultivation, with approximately $8 \%$ of the cultivated area in the country $(21,209$ ha). Espírito Santo is the main producing state in the region, with 11,126 ha ( $4 \%$ of the production area); followed by Rio de Janeiro, with 4,458 ha (1.6\%); São Paulo, with 3,134 ha (1\%); and Minas Gerais, with 2,491 ha $(0.9 \%)$ (Instituto Brasileiro de Geografia e Estatística, 2011). For the reference period, extensive areas were considered unfavorable for red palm mite populations, particularly from April to September in a wide eastern belt. From April to June, almost the entire region was considered unfavorable, except for some areas in the west of the state of São Paulo that were forecasted as favorable. According to the A2 scenario, a significant reduction would occur in the unfavorable areas of this region, which would be replaced by mostly favorable and very favorable extensive areas.

For the reference period, the predominant conditions in the state of Espírito Santo were considered unfavorable or less favorable for red palm mite population growth; only from January to March some areas of the state were classified as favorable. Under the A2 scenario, favorable conditions would prevail in the state for nine months (August-April), and less favorable conditions, from May to July. Therefore, red palm mite populations should not reach high densities in this state in the reference period, but should reach high densities under the A2 climate change scenario. Similar results were forecasted for Minas Gerais and western São Paulo. Under the A2 scenario, most of 
Minas Gerais and western São Paulo were favorable or very favorable for red palm mite populations, which suggests that the pest could be established and reach high densities. In the Southeast region, very favorable conditions were observed for Minas Gerais and São Paulo, mainly from August to November, for both the reference period and the A2 scenario; however, these areas are more extensive under the $\mathrm{A} 2$ scenario.

In the state of Rio de Janeiro, the conditions should be unfavorable or less favorable for almost the whole year in the reference period. Similarly, under the A2 scenario, prevailing conditions should be less favorable, except for some months (January and September-November) when conditions should be favorable in some areas. In this state, even under the A2 scenario, the red palm mite would most likely not be established or populations would remain at densities unable to cause damages.

The Midwest region contains about 1\% (2,801 ha) of the total acreage planted to coconut in Brazil. In this region, coconut is grown primarily in the states of Mato Grosso, with 1,302 ha $(0.5 \%$ of the production area), and of Goiás, with 1,163 ha $(0.4 \%)$ (Instituto Brasileiro de Geografia e Estatística, 2011). Although still small, coconut cultivation is increasing in this region. Analyses showed that, for the reference period, unfavorable areas for red palm mite populations would be restricted in both space and time. For most of the year, the majority of the area in this region would vary from less favorable to very favorable. Under the A2 scenario, between 2071-2100, the unfavorable areas should turn into favorable or very favorable ones.

For the reference period, the northern part of Mato Grosso would be less favorable for the pest between January-May and October-December, whereas the southern part would be favorable or very favorable from May and July to December. Under the A2 scenario, less favorable conditions would still occur, primarily in the northern part of the state for six months (November-April), and favorable or very favorable areas should prevail from May to October. Due to the scarce information available on population dynamics and on the damage level for the red palm mite, it is not possible to infer whether, in this state, the pest would reach damaging levels under the A2 scenario.

In the state of Goiás, conditions were forecasted as favorable or very favorable for the reference period, except for some areas that would be unfavorable or less favorable from November to May. For this state, under the A2 scenario, unfavorable areas would disappear along the whole year, whereas less favorable or favorable areas would be largely replaced by favorable and very favorable ones, respectively. These results suggest that, in Goiás, the pest population could reach high densities under the reference period and the A2 scenario.

Coconut acreage in the state of Mato Grosso do Sul is currently very limited (336 ha) (Instituto Brasileiro de Geografia e Estatística, 2011). Under the reference period, conditions for red palm mite populations would be unfavorable (May-June) or less favorable (JanuaryMarch) for approximately six months; therefore, the establishment of the pest would probably not occur, despite the prevalence of favorable or very favorable conditions from July to December. Conversely, under the A2 scenario, unfavorable areas would disappear and conditions should be favorable (November-June) or very favorable (July-October) for the pest populations. Under these circumstances, the pest could reach high densities in this state and represent a phytosanitary problem if the area with coconut cultivation increases.

In the South region, coconut cultivation is very small, being restricted to the northern part of the state of Paraná, where the cultivated area does not reach 200 ha (Instituto Brasileiro de Geografia e Estatística, 2011). Conditions in this region would be unfavorable during most of the year in the reference period and in the A2 scenario, except for the extreme north of Paraná (September-March) and for western Rio Grande do Sul (November-February). Under the A2 scenario, a notable reduction of unfavorable areas during the summer months (December-March) was forecasted, and these areas were replaced by favorable or very favorable conditions; however, for other periods, the conditions would remain mostly unfavorable. Under this climate change scenario, if coconut were widely cultivated in this region, red palm mite should not be established in most areas, due to the long period with unfavorable conditions, except for northern Paraná where conditions were favorable or very favorable for most of the year.

Amaro \& Morais (2013) estimated the potential geographical distribution of red palm mite in South America for the period of $\sim 1950-2000$, using a maximum entropy model. Their results were quite different from those obtained in the present study, 
probably due to the different methodology and approach adopted by them. According to these authors, the most suitable areas for this pest would be mainly restricted to the coastal zones and to the Amazon basin, whereas inland areas of the Northeast region presented low or moderate probability of occurrence. However, forecasting in the present study showed that coastal zones, mainly from Rio Grande do Norte to São Paulo, should be unfavorable or less favorable for the pest along several months (April-September); that inland areas of the Northeast region would be favorable or very favorable along the whole year, standing out as the most favorable areas in the country; and that less favorable conditions would prevail in the Amazon basin (Figures 1 to 3 ). The results obtained in this prediction are largely consistent with the red palm mite population dynamics available in the literature. Although temperature could be favorable for the red palm mite along the Brazilian coastal areas, densities could be seriously affected by high rainfall. Studies in different countries have shown that densities of this mite are positively correlated with low relative humidity and low rainfall. In India, Nageshachandra \& Channabasavanna (1984) and Taylor et al. (2012) observed that the numbers of mites decreased rapidly with the onset of the rainy season. A similar situation was found in the Mauritius island, where red palm mites were less abundant during the heavy rain period, from November to January (Moutia, 1958). In the state of Roraima, from March 2010 to February 2011, densities of mites declined rapidly after the first sampling date, with increasing rainfall and decreasing temperatures (May-September); upward trends in population levels were observed between October and November and January and February, coinciding with preceding periods of low rainfall (Gondim Jr. et al., 2012).

In addition to abiotic factors, the invasive pest distribution and population density should be affected by biotic factors. The main biotic factors influencing pests are the availability and the physiological conditions of the host plants. According to Zullo Júnior et al. (2012), the Brazilian agricultural scenario could be changed to the extent that tropical fruits could be cultivated in southern Brazil. Although coconut agroclimatic zoning has not yet been defined for climate change scenarios, it is possible that the cultivated areas would increase, expanding to regions where the crop is still not cultivated (Warwick et al., 2011). Under this forecasting scenario, host plant availability would not be a limitation for red palm mite distribution in the country.

Biological control with predatory mites has been considered a promising strategy to minimize red palm mite impact in the Americas (Moraes et al., 2012). It is know that changes in environmental conditions may affect trophic interactions, as predation rate. Furthermore, the efficiency or life history of natural enemies can be negatively affected by environmental warming. The reduction in the efficiency of predatory mites on invasive mite pests under warming conditions may also occur, for instance, due to differences in the thermal performance in predator and prey (Montserrat et al., 2013). Therefore, the risk of efficiency reduction in predatory mites on red palm mite under future climate conditions should be taken into account when defining the biological control strategies for this invasive pest. The applied forecasting methodology allowed for both spatial and temporal analyses, which were then integrated. The spatial prediction on the favorability levels enabled analyses of the effects of climate changes on the pest distribution in both current and potential agroclimatic zones of the threatened crop. The temporal prediction on the favorability levels along the year allowed for inferences related to the current and future population dynamics and its consequences. For a specific locality, the number of months in which the pest would have favorable or very favorable conditions would determine whether it can be established and if it can reach damaging population densities (Lockwood et al., 2005).

\section{Conclusions}

1. Brazil currently has extensive areas with favorable or very favorable conditions to the establishment of red palm mite (Raoiella indica) populations.

2 . The potential impact of the invasive red palm mite for most Brazilian regions will worsen under climate change scenarios when compared with the reference period, in the main coconut (Cocos nucifera) production areas and in the regions where the crop is in expansion.

3. Under current and future climate change scenarios, most of the favorable and very favorable areas for red palm mite are in northeastern Brazil, the first coconut-producing region in the country. 


\section{Acknowledgements}

To Empresa Brasileira de Pesquisa Agropecuária (Embrapa) and to Conselho Nacional de Desenvolvimento Científico e Tecnológico (CNPq), for financial support and fellowships.

\section{References}

AMARO, G.; MORAIS, E.G.F. de. Potential geographical distribution of the red palm mite in South America. Experimental and Applied Acarology, v.60, p.357-365, 2013. DOI: 10.1007/ s10493-012-9651-9.

BURGIEL, S.W.; MUIR, A.A. Invasive species, climate change and ecosystem-based adaptation: addressing multiple drivers of global change. Washington: Global Invasive Species Programme, 2010. 55p.

BRASIL. Instrução normativa $n^{\circ}$ 59, de 18 de dezembro de 2013. Exclui da lista de pragas quarentenárias ausentes as pragas acarinaRaoiella indica; hemíptera-Maconellicoccus hirsutus; lepidoptera - Helicoverpa armígera; fungo - Puccinia kuehnii e virus - Lily symptomless. Diário Oficial [da] República Federativa do Brasil, 19 dez. 2013. Seção 1, p.91-92.

CARRILlO, D.; AMALIN, D.; HOSEIN, F.; RODA, A.; DUNCAN, R.E.; PEÑA, J.E. Host plant range of Raoiella indica (Acari: Tenuipalpidae) in areas of invasion of the New World. Experimental and Applied Acarology, v.57, p.271-289, 2012. DOI: $10.1007 / \mathrm{s} 10493-011-9487-8$.

CLIMATE RESEARCH UNIT. Climate Research Unit. Available at: <http://www.cru.uea.ac.uk/>. Accessed on: 20 Sept. 2015.

FLECHTMANN, C.H.W.; ETIENNE, J. The red palm mite, Roiella indica Hirst, a threat to palms in the Americas (Acari: Prostigmata: Tenuipalpidae). Systematic and Applied Acarology, v.9, p.109-110, 2004

FONTES, H.R.; WANDERLEY, M. Situação atual e perspectivas para a cultura do coqueiro no Brasil. Aracaju: Embrapa Tabuleiros Costeiros, 2006. 16p. (Embrapa Tabuleiros Costeiros. Documentos, 94).

FRANKLIN, J. Mapping species distributions: spatial inference and prediction. Cambridge: Cambridge University, 2009. 320p.

GHINI, R.; HAMADA, E.; BETTIOL, W. Climate change and plant diseases. Scientia Agricola, v.65, p.98-107, 2008. DOI: 10.1590/S0103-90162008000700015.

GONDIM JR., M.G.C.; CASTRO, T.M.M.G.; MARSARO JUNIOR, A.L.; NAVIA, D.; MELO, J.W.S.; DEMITE, P.R.; MORAES, G.J. Can the red palm mite threaten the Amazon vegetation? Systematics and Biodiversity, v.10, p.527-535, 2012. DOI: $10.1080 / 14772000.2012 .752415$.

HELLMANN, J.; BYERS, J.E.; BIERWAGEN, B.; DUKES, J. Five potential consequences of climate change for invasive species. Conservation Biology, v.22, p.534-543, 2008. DOI: 10.1111/j.152 3-1739.2008.00951.x.
HOUGHTON, J.T.; DING, Y.; GRIGGS, D.J.; NOGUER, M.; VAN DER LINDEN, P.J.; DAI, X.; MASKELL, K.; JOHNSON, C.A. (Ed.). Climate change 2001: the scientific basis. Geneva: Cambridge University, 2001. 881p. (IPCC. Assessment report, 3).

INTERGOVERNMENTAL PANEL ON CLIMATE CHANGE. IPCC Data Distribution Centre. Available at: $<$ http://www. ipcc-data.org/>. Accessed on: 20 Sept. 2015.

INSTITUTO BRASILEIRO DE GEOGRAFIA E ESTATÍSTICA. Produção agrícola municipal. 2011. Disponível em: <http:// www.ibge.gov.br/home/estatistica/economia/pam/2011/>. Acesso em: 30 nov. 2014 .

LEWIS, S.L.; BRANDO, P.M.; PHILLIPS, O.L.; VAN DER HEIJDEN, G.M.F.; NEPSTAD, D. The 2010 Amazon drought. Science, v.331, p.554, 2011. DOI: 10.1126/science.1200807.

LOCKWOOD, J.L.; CASSEY, P.; BLACKBURN, T.M. The role of propagule pressure in explaining species invasions. Trends in Ecology and Evolution, v.20, p.223-228, 2005. DOI: 10.1016/j. tree.2005.02.004.

MONTSERRAT, M.; SAHÚN, R.M.; GUZMÁN, C. Can climate change jeopardize predator control of invasive herbivore species? A case study in avocado agro-ecosystems in Spain. Experimental and Applied Acarology, v.59, p.27-42, 2013.

MORAES, G.J. de; CASTRO, T.M.M.G. de; KREITER, S.; QUILICI, S.; GONDIM JR., M.G.C.; SÁ, L.A.N. Search for natural enemies of Raoiella indica Hirst in Reunion Island (Indian Ocean). Acarologia, v.52, p.129-134, 2012. DOI: 10.1051/ acarologia/20122043.

MOUTIA, L.A. Contribution to the study of some phytophagous acarina and their predators in Mauritius. Bulletin of Entomological Research, v.49, p.59-75, 1958. DOI: 10.1017/ S0007485300053438.

NAGESHACHANDRA， B.K.; CHANNABASAVANNA， G.P. Plant mites. In: GRIFFTHS, D.A.; BOWMAN, C.E. (Ed.). Acarology VI. West Sussex: Ellis Horwood Publishers, 1984. p.785-790.

NAVIA, D.; MARSARO JUNIOR, A.L.; SILVA, F.R. da; GONDIM JR., M.G.C.; MORAES, G.J. First report of the Red Palm Mite, Raoiella indica Hirst (Acari: Tenuipalpidae), in Brazil. Neotropical Entomology, v.40, p.409-411, 2011. DOI: 10.1590/ S1519-566X2011000300018.

NELSON, G.C.; ROSEGRANT, M.W.; KOO, J.; ROBERTSON, R.; SULSER, T.;ZHU, T.; RINGLER, C.; MSANGI, S.; PALAZZO, A.; BATKA, M.; MAGALHAES, M.; VALMONTE-SANTOS, R.; EWING, M.; LEE, D. Climate change: impact on agriculture and costs of adaptation. Washington: International Food Policy Research Institute, 2009. 19p.

PEÑA, J.E. Potential invasive pests of agricultural crops. Wallingford: CAB International, 2013. 440p. (CABI invasives series, 1). DOI: 10.1079/9781845938291.0000.

RODRIGUES, J.C.V.; ANTONY, L.M.K. First report of Raoiella indica (Acari: Tenuipalpidae) in Amazonas state, Brazil. Florida Entomologist, v.94, p.1073-1074, 2011. DOI: 10.1653/024.094.0452. 
TAYLOR, B.; RAHMAN, P.M.; MURPHY, S.T.; SUDHEENDRAKUMAR, V.V. Within-season dynamics of red palm mite (Raoiella indica) and phytoseiid predators on two host palm species in south-west India. Experimental and Applied Acarology, v.57, p.331-345, 2012. DOI: 10.1007/ s10493-011-9482-0.

WARWICK, D.R.N.; TALAMINI, V.; CARVALHO, R.R.C.; SILVA, A.M.F. Impacto potencial das mudanças climáticas sobre as doenças do coqueiro no Brasil. In: GHINI, R.; HAMADA, E.; BETTIOL, W. (Ed.). Impactos das mudanças climáticas sobre doenças de importantes culturas no Brasil. Jaguariúna: Embrapa Meio Ambiente, 2011. p.201-210.
WHEELER, T.; VON BRAUN, J. Climate change impacts on global food security. Science, v.341, p.508-513, 2013. DOI: 10.1126/science. 1239402 .

ZISKA, L.H.; BLUMENTHAL, D.M.; RUNION, G.B.; HUNT JUNIOR, E.R.; DIAZ-SOLTERO, H. Invasive species and climate change: an agronomic perspective. Climatic Change, v.105, p.13-42, 2011. DOI: 10.1007/s10584-010-9879-5.

ZULLO JÚNIOR, J.; ASSAD, E.D.; PINTO, H.S. Alterações devem deslocar culturas agrícolas: café pode desaparecer do Sul de Minas e frutas tropicais poderão ser cultivadas no sul do país. Scientific American Brasil, n.48, p.70-75, 2012. Edição especial.

Received on November 30, 2014 and accepted on August 27, 2015 